\title{
THE PO'TENTIAL OF THE HYDROGEN-OXYGEN CELL.
}

\author{
BY FRANCIS JOSEPH BRISLEE, M.Sc.*
}

(A Paper read before the Faraday Society on Wednesday, November 23, I904, Mr. W. R. Cooper in the Chair.)

The potential of the galvanic cell-

$\left.\begin{array}{l}\text { Platinised Platinum } \\ \text { Charged with Hydrogen }\end{array}\right\} \frac{\mathrm{N}}{\mathrm{I}}$ acid $\left\{\begin{array}{l}\text { Platinised Platinum } \\ \text { Charged with Oxygen }\end{array}\right.$

has been measured by various experimenters and found to lie between r.076 and I' ${ }_{4} 4$ volts. Wilsmore (Zeit. Physik. Chem. 35 (I900), 29I) observed that hydrogen peroxide was formed in the oxygen electrode compartment after standing for three or four days, and after seventeen days the observed potential was $\mathrm{x} \cdot \mathrm{x} \mathrm{I} 7 \mathrm{volt}$.

Czepinski (Zeit. Anorg. Chem. 30 (1902), I) made a series of measurements of the hydrogen-oxygen potential, and found that the highest potential reached (after I4 days) was I'I 20 volt. Preuner (Zeit. Physik. Chem. 42 (1903), 50) calculated the potential of the cell from thermodynamic considerations and found $\mathrm{r}^{\cdot} \mathrm{r} 5$ volt at $20^{\circ}$. Bose (Zeit. Physik. Chem. 34 (I900), 7or, 38 (rgor), I) found $\mathrm{I}^{\circ} \mathrm{I}_{4}$ volt at $25^{\circ} \mathrm{C}$. as the result of a very long and laborious investigation. In Bose's experiments, the platinised platinum electrodes were charged with hydrogen and oxygen by electrolysis, the electrolysis being continued for two or three days to ensure complete saturation of the electrodes with the respective gases. The potential measurements were made in the same liquid in which the electrodes were polarised. The temperature was kept constant at $25^{\circ} \mathrm{C}$.

It is by no means impossible or unlikely that a little persulphuric acid, hydrogen peroxide and ozone may have been formed by the electrolysis, and the following investigations were undertaken with a view to determining the influence of traces of these substances upon the oxygen potential.

Two lines of work were followed: Ist, the electrodes were polarised by electrolysis; the electrolysis extending over two or three days; and 2nd, the electrodes were freed from gases as completely as possible, and then the respective gases passed through the liquid and the potential measured from time to time until constant.

By these means two potential limits were obtained-the first, starting from a high potential and gradually sinking, and the second rising to a constant value.

When the potentials were constant to about I-2 millivolts, the effect of the addition of the various substances was tried.

* Communicated by Professor F. Campbell Brown, D.Sc. 


\section{EXPERIMENTAL Part.}

The electrodes consisted of platinum plates $2 \times 5 \mathrm{~cm}$. and o $1 \mathrm{~mm}$. thick, to each of which a piece of stout platinum wire was welded and fused into a glass tube. Electrodes were also made by covering a glass tube with a very thin coating of platinum prepared by painting with the "Glanz Platin" made by the Deutsche Gold und Silber Scheideanstalt, Frankfort, allowing to dry, and then igniting in a muffle until the glass began to soften. Three or four coats were required to form a coating of platinum of satisfactory thickness. Electrical connection was made by a piece of platinum wire fused through the lower end of the glass tube. The deposit of platinum so obtained is firm and bright, conducts well, and can be platinised in the usual way. Gold electrodes were made similarly, employing the "Glanz Gold" prepared by the same firm. The electrodes were thoroughly cleaned in chromic acid, well washed with distilled water, and then platinised, using the solution recommended by Lummer and Kurlbaum. Traces of chlorine were removed by electrolysing dilute sulphuric acid, changing the poles from time to time. The electrodes were again cleaned with boiling nitric acid, hydrochloric acid, caustic soda, and finally washing well in distilled water. They were then joined together by a wire and allowed to stand in a solution of ferrous and ferric sulphate for 20-30 minutes, again well washed with distilled water, and then with the acid to be employed in the measurements. Electrodes so prepared showed no potential between each other, or at most one or two hundredths of a millivolt. This short-circuiting in a ferrous-ferric sulphate solution was employed in every case, to remove gases from the electrodes as completely as possible, and so ensure uniform and comparable conditions at the commencement of every experiment. The hydrogen was prepared-Ist, by the electrolysis of $I: 6$ sulphuric acid, and sodium hydrate solution; 2 nd, by the reaction of aluminium and sodium hydrate; and 3 rd, from zinc and dilute hydrochloric acid. The gas was carefully purified by washing with lead acetate solution, alkaline permanganate solution, water, and finally with acid of the same strength as that employed in the measuring apparatus. The oxygen was prepared-ist, by electrolysis of sodium hydrate solution, and any ozone was destroyed by passing the oxygen through a red-hot tube before washing the gas; 2nd, by heating potassium permanganate. Brin's oxygen was also employed. Analysis showed a content of $99 \cdot 3$ per cent. oxygen. The oxygen was washed in strong sodium hydrate solution, in alkaline potassium permanganate, and then in the same strength of acid used in the electrode compartment.

A series of measurements of the hydrogen-oxygen potential employing the gases from the above sources showed a very good agreement.

\section{TABLE I.}

\begin{tabular}{|c|c|}
\hline Source of the Oxygen and Hydrogen. & $\begin{array}{c}\text { Potential of }{ }^{\mathrm{Pt}_{\mathrm{H}_{2}}} / \frac{\mathrm{N}}{\mathrm{T}} \mathrm{H}_{2} \mathrm{SO}_{4} / \mathrm{Pt}_{\mathrm{O}_{2}} \\
\mathrm{~T}=18^{\circ} \mathrm{C} .\end{array}$ \\
\hline $\begin{array}{llllll}\text { Electrolytic } & \ldots & \ldots & \ldots & \ldots & \ldots\end{array}$ & I’0820 volt \\
\hline Aluminium and $\mathrm{NaOH}$, and permanganate & r.083o , \\
\hline Zinc and hydrochloric acid, Brin's oxygen & I.0818, \\
\hline
\end{tabular}




\section{POTENTIAL OF THE HYDROGEN-OXYGEN CELL O7}

The essential parts of the apparatus for containing the electrodes are shown in the figure. The tube $A$ is $3.5 \mathrm{~cm}$. wide and $15 \mathrm{~cm}$. long, fitted with a paraffined cork or rubber stopper. Through this pass the tube bearing the platinum electrode, and a small electrode $\mathrm{C}$, which consists of a piece of platinum wire $2-3 \mathrm{~mm}$. long. The gas after passing through the wash bottles passes in through $\mathrm{B}$, and issues through an exit tube, fitted with a small wash bottle containing the same acid as $\mathrm{A}$, which prevents air diffusing back into the apparatus. The arrangement $\mathrm{D}$ serves to connect the apparatus with the normal electrode, either $\mathrm{Hg} / \mathrm{Hg}_{2} \mathrm{SO}_{4} \frac{\mathrm{N}}{\mathrm{I}} \mathrm{H}_{2} \mathrm{SO}_{4} /$ or $\mathrm{Pt}_{\mathrm{H}_{2}} / \frac{\mathrm{N}}{\mathrm{I}} \mathrm{H}_{2} \mathrm{SO}_{4} / /$ was employed, and the tap was kept closed during the measurements. This form of apparatus was used for the oxygen electrode in the following experiments.

The hydrogen electrode is similar, and is likewise stown in the figure.

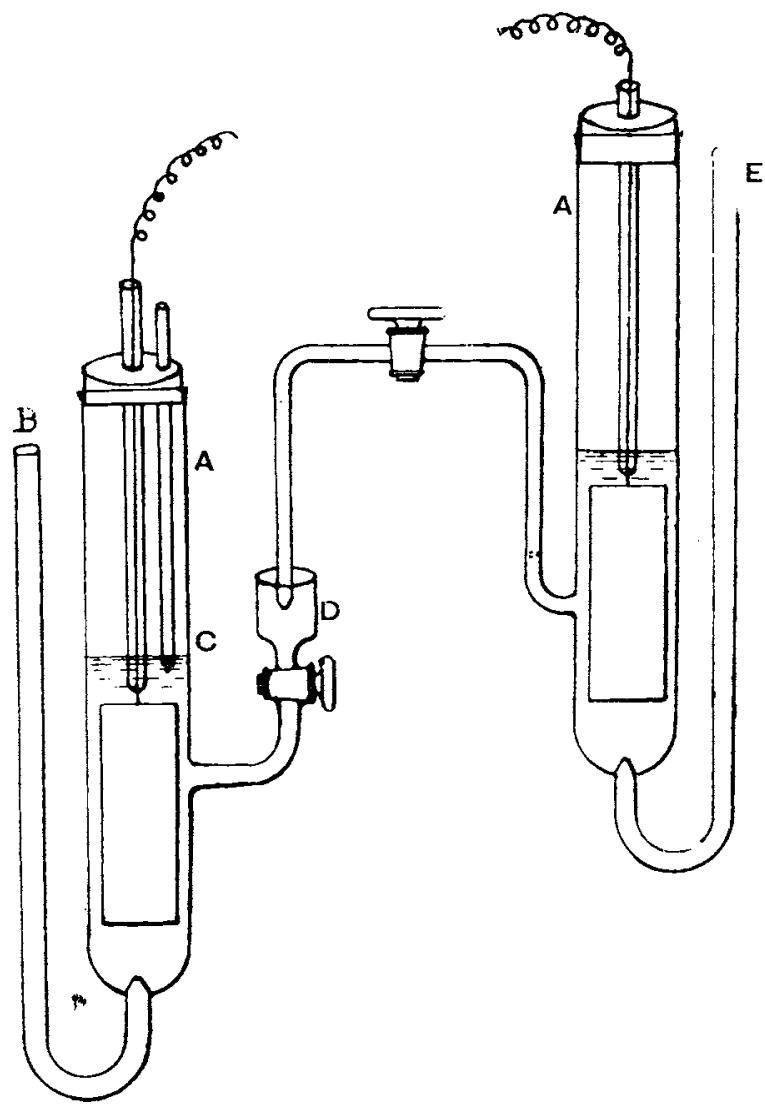

The cup D is replaced by a syphon tube and tap which serve to connect it with the oxygen electrode.

The hydrogen electrode was filled with the same strength of acid as that used in the oxygen electrode, and the tap kept closed during the measurements. 
The measurements of the potential were made by the Poggendorf-du Bois Reymond compensation method. An accumulator was used as an auxiliary cell, and a Weston cadmium element served as a standard cell. The Weston element was compared with a certified cell and found to be correct. A Lippmann's capillary electrometer was employed as a null instrument. This was sensitive to o'or millivolt.

The method of making the measurements was the following: The electrodes and vessels were carefully cleaned, short-circuited in a ferrousferric solution, and again washed as explained above (compare Luther and Inglis (Zeit. Physik. Chem. 43 (1903), 210). The vessels were then rather more than half filled with the acid or alkali; normal solutions were employed as a rule. After rinsing the electrodes with the liquid to be used in the cell, they were placed in position in the electrode vessels. Electrodes so prepared showed no potential difference between each other. When measured against the constant hydrogen electrode, the combination showed a potential difference of about 0.8 volt. The vessels were then placed in an air thermostat and the temperature regulated; so that during the experiment the variation of temperature was not more than $0^{\circ} 25^{-0} 0^{\circ} \mathrm{C}$.

The hydrogen electrode was similarly adjusted and put into combination with the electrode to be measured, as shown in the figure.

The gas was then bubbled through the liquid in the electrode vessels in a moderately rapid stream, and the potential measured from time to time; the potential of the hydrogen electrode was measured against the normal electrode $\mathrm{Hg} / \mathrm{Hg}_{2} \mathrm{SO}_{4} \frac{\mathrm{N}}{\mathrm{I}} / / \mathrm{H}_{2} \mathrm{SO}_{4} / / \pi\left(\mathrm{Hg}-\frac{\mathrm{N}}{\mathrm{I}} \mathrm{H}_{2} \mathrm{SO}_{4}\right)=+0^{\circ} 95^{6}$ volt, in order to insure constancy.

The hydrogen electrode gave a constant potential difference-

$$
\pi_{\mathrm{H}_{2}-\frac{\mathrm{N}}{2} \mathrm{H}_{2} \mathrm{SO}_{4}}=+0.278 \text { volt }
$$

in five to ten minutes from the commencement of the gas current. If it was desired to add a small quantity of a solution of ozone, hydrogen peroxide or persulphate, the gas current was interrupted for a moment, the measured volume of the solution introduced into the tube $\mathrm{E}$ by means of a pipette, and mixed with the solution by continuing the current of gas. The potential difference was measured immediately after mixing, and at intervals until a constant value was reached.

The change of potential of the combination $\mathrm{Pt}_{\mathrm{H}_{2}} / \frac{\mathrm{N}}{\mathrm{I}} \mathrm{H}_{2} \mathrm{SO}_{4} / \mathrm{Pt}_{\mathrm{O}_{2}}$ with time was then measured. The electrodes (platinum plates) were freed from gases by the ferro-ferric solution, and then hydrogen and oxygen were led into the acid contained in the vessels. The cell showed a constant potential difference in 24 hours after the commencement and remained constant for three days. Table II. shows the results of the measurements.

After the third day the P.D. began to rise, and even on checking the gas current it did not sink to its original value. After standing with a current of gas passing for three weeks, the P.D. sank to $r^{\circ} 054$ volt and did not again rise. The temperature and other conditions remained unaltered. The hydrogen electrode was tested against the normal $\mathrm{Hg} / \mathrm{Hg}_{2} \mathrm{SO}_{4} \frac{\mathrm{N}}{\mathrm{I}} \mathrm{H}_{2} \mathrm{SO}_{4} / /$ electrode, and was found to remain unaltered. The liquid in the oxygen compartment was emptied out and tested. The liquid decolourised permanganate solution, liberated iodine from potassium iodide and gave the characteristic blue colouration when shaken with chromic acid and ether. 
POTENTIAL OF THE HYDROGEN-OXYGEN CELL 69

TABLE II.

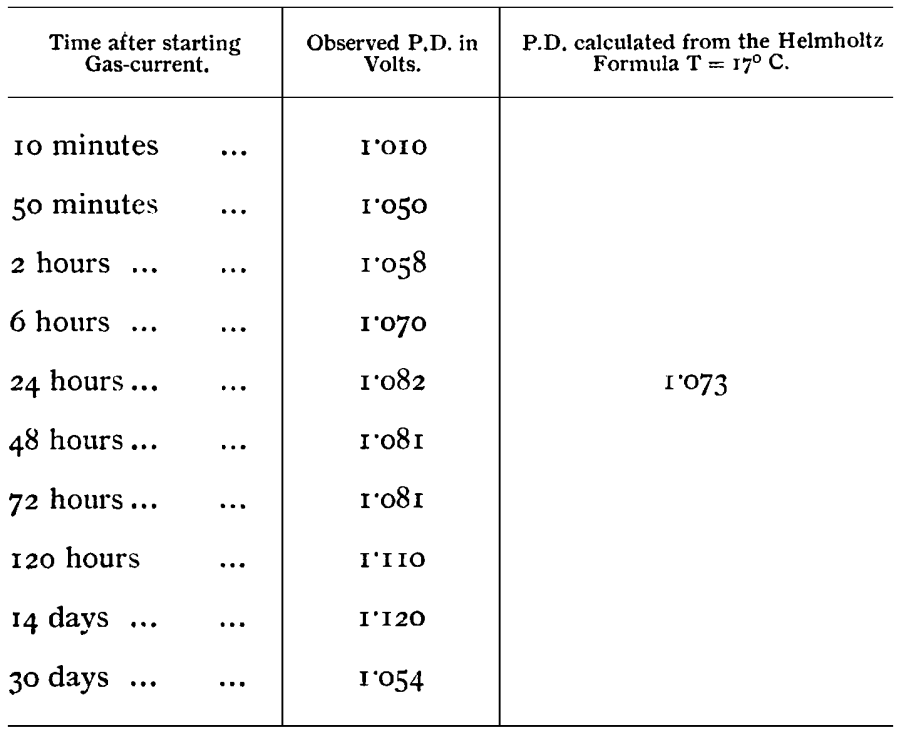

Blank experiments were made with the acid, etc., employed, to ensure the reagents employed being free from substances giving these reactions. This points to the formation of hydrogen peroxide in the anode compartment and confirms the observation of Wilsmore (loc. cit.).

\section{Influence of Hydrogen Peroxide upon the Oxygen Potential.}

The influence of hydrogen peroxide upon the oxygen potential was next tried. The cell was arranged precisely as in the preceding case, and when the potential difference reached a constant value of $\mathrm{I} \cdot 08 \mathrm{o}$ volt, $2 \mathrm{cc}$. of $\mathrm{N}$ hydrogen peroxide solution were added. The P.D. immediately sank to below I volt. The rapidity of the oxygen current was increased, but on standing for six days, the cell did not regain its original potential, although the temperature, etc., were maintained constant. These results are shown below:-

Table III.

\begin{tabular}{|c|c|}
\hline & $\begin{array}{l}\text { Potential in Volts of } \\
\mathrm{Pt}_{\mathrm{H}_{2}} / \frac{\mathrm{N}}{\mathrm{I}} \mathrm{H}_{2} \mathrm{SO}_{4} / \mathrm{Pt}_{\mathrm{O}_{2}}\end{array}$ \\
\hline P.D. before adding $\mathrm{H}_{2} \mathrm{O}_{2} \quad \ldots$ & I'08o \\
\hline $\begin{array}{l}\text { Immediately after addition of } \\
2.0 \mathrm{cc} . \frac{\mathrm{N}}{\mathrm{IOO}} \mathrm{H}_{2} \mathrm{O}_{2} \text { solution } \ldots\end{array}$ & $0^{\prime} 980$ \\
\hline 28 hours later ... & $\mathrm{I} \cdot 054$ \\
\hline 6 days $\ldots \quad \ldots \quad \ldots \quad \ldots$ & I'054 \\
\hline
\end{tabular}




\section{POTENTIAL OF THE HYDROGEN-OXYGEN CELL}

The liquid in the oxygen compartment gave the reactions of hydrogen peroxide, even after standing for six days.

An experiment carried out similarly employing $\frac{\mathrm{N}}{\mathrm{I}} \mathrm{NaOH}$ solution gave the same result. The influence of the addition of hydrogen peroxide upon the oxygen potential was next tried upon electrodes supersaturated with oxygen gas by long polarisation. The cell (arranged in Fig. I.) was connected through a lamp resistance, with the I lo-volt mains. The large platinised platinum electrode $\mathrm{E}$ formed the anode, the small platinum point $\mathrm{C}$ the cathode. A current of about 0.5 ampere was passed for 72 hours, oxygen gas being bubbled through the liquid to remove the hydrogen as rapidly and completely as possible. After polarising, this cell was combined with a constant hydrogen electrode and the P.D. measured.

These results are given in Table III.

TABLE IV.

\begin{tabular}{|c|c|c|c|c|c|}
\hline \multicolumn{3}{|c|}{$\begin{array}{l}\text { Time after stopping } \\
\text { Polarising Current. }\end{array}$} & \multirow{2}{*}{\begin{tabular}{c|}
$\underset{{ }^{\circ} \mathrm{C} .}{\text { Temp. }}$ \\
Inconst.
\end{tabular}} & \multirow{2}{*}{ 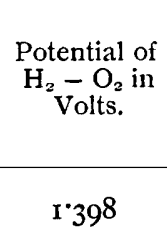 } & \multirow{2}{*}{$\begin{array}{c}\text { Potential of } \mathrm{Pt}_{\mathrm{O}_{2}}-\frac{\mathrm{N}}{\mathrm{I}} \mathrm{H}_{2} \mathrm{SO}_{4} . \\
\pi_{\mathrm{H}_{2}} / \frac{\mathrm{N}}{\mathrm{I}} \mathrm{H}_{2} \mathrm{SO}_{4} / /=+\mathrm{o}^{\circ} 277 \text { voit. } \\
\ldots .\end{array}$} \\
\hline I minute & $\ldots$ & $\ldots$ & & & \\
\hline 30 minutes & $\ldots$ & ... & $20^{\circ}$ & I.475 & $-I \cdot 198$ \\
\hline 24 hours & $\ldots$ & .. & ", & I'377 & $-1 \cdot 100$ \\
\hline $4^{8}$ hours & $\ldots$ & $\ldots$ & $"$ & I.350 & $-\mathrm{r} \cdot 073$ \\
\hline $2 \mathrm{ccc} \cdot \frac{\mathrm{N}}{\mathrm{IOO}} \mathrm{H}_{2}$ & sol.ad & & ", & Below I volt & $\ldots$ \\
\hline I hr. after a & ding $\mathrm{H}$ & ${ }_{2} \mathrm{O}_{2}$ & ", & r.064 & -0.837 \\
\hline 24 hours lat & $\cdots$ & $\cdots$ & $"$ & r.o33 & $-0.75^{6}$ \\
\hline 7 days later & $\ldots$ & $\ldots$ & $"$ & $I \cdot 03 I$ & -0.754 \\
\hline
\end{tabular}

The liquid upon testing decolourised a solution of potassium permanganate, liberated iodine from potassium iodide solution, and gave the bluc colouration with potassium dichromate and ether.

These experiments indicate that hydrogen peroxide is not completely decomposed by platinised platinum, and that the presence of a small quantity in the anode compartment lowers the oxygen potential.

This confirms the view expressed by Fredenhagen (Zeit. Anorg. Chem. 29 (1902), 396) regarding the potential of hydrogen peroxide. The quantity of hydrogen peroxide added corresponded to about I gram. mol. $\mathrm{H}_{2} \mathrm{O}_{2}$ in $\mathrm{I}, 000$ litres.

\section{Influence of Persulphate upon the Oxygen Potential.}

Elbs and Schönherr (Zeit. Elektrochem. I, 468) have shown that persulphates decompose water with evolution of oxygen, and as a result of this decomposition, under favourable conditions the formation of hydrogen peroxide may result. 


\section{POTENTIAL OF THE HYDROGEN-OXYGEN CELL 7I}

If, then, the solution contains a measurable quantity of persulphate ions, the potential will be above the potential of the corresponding oxygen electrode.

Price (Zeit. Physik. Chem. 27 (1898), 5II) states that it is not possible to measure the potential in a persulphate solution, and this view was confirmed by Fredenhagen (Zeit. Anorg. Chem. 29 (I9O2)).

Fredenhagen obtained a potential difference of $-\mathrm{r}^{\cdot} 5$ volt in $\frac{\mathrm{N}}{\mathrm{IO}} \mathrm{H}_{2} \mathrm{SO}$ saturated with potassium persulphate after standing for 24 hours.

In the following experiments very dilute solutions of persulphates were employed. Preliminary experiments confirmed the results of Price and Fredenhagen. Employing $\frac{\mathrm{N}}{\mathrm{IO}} \mathrm{K}_{2} \mathrm{~S}_{2} \mathrm{O}_{8}$ in $\frac{\mathrm{N}}{\mathrm{I}} \mathrm{H}_{2} \mathrm{SO}_{4}$, a gradually rising potential was obtained, commencing at $\mathrm{I}^{\circ} 05^{8}$, rapidly rising to $\mathrm{I}^{\cdot 268}$ volt in two hours, and reaching $\mathrm{I}_{4} 4 \mathrm{I} 7$ in 24 hours.

An experiment was then tried employing a very small quantity of persulphate solution. The electrodes were carefully cleaned and freed from gases by the ferrous-ferric solution. The apparatus was then adjusted and oxygen gas passed in, and the potential measured against the constant hydrogen electrode. When the combination showed a constant potential of I.08I volt, I cc. $\frac{\mathrm{N}}{\mathrm{IOO}} \mathrm{K}_{2} \mathrm{~S}_{2} \mathrm{O}_{8}$ was added to the $\frac{\mathrm{N}}{\mathrm{I}}$ sulphuric acid in the anode compartment. The oxygen current was again continued, and the potential measured. The potential reached a constant value of $I^{\cdot} \cdot 22$ volts, and remained constant for five days. The concentration of the persulphate in the anode compartment corresponded to I mol. of $\mathrm{K}_{2} \mathrm{~S}_{2} \mathrm{O}_{8}$ in 5,000 litres.

At the end of the fifth day no hydrogen peroxide could be detected by the usual tests, the solution giving the reactions of the persulphates only. A parallel experiment employing $\frac{\mathrm{N}}{\mathrm{I}} \mathrm{NaOH}$ as the electrolyte gave the same results upon adding a small quantity of potassium persulphate solution.

The electrodes, after cleaning and freeing from gases, were polarised for 72 hours. After polarising, the apparatus was allowed to stand until it gained a constant temperature, and the potential measured. One cc. $\frac{\mathrm{N}}{\mathrm{IO}} \mathrm{K}_{2} \mathrm{~S}_{2} \mathrm{O}_{8}$ was then added, the current of oxygen gas continued, and the potential measured from time to time.

Table V.

\begin{tabular}{|c|c|c|}
\hline & $\begin{array}{c}\text { Potential of } \\
\mathrm{Pt}_{\mathrm{H}_{2}} / \frac{\mathrm{N}}{\mathrm{I}} \mathrm{H}_{2} \mathrm{SO}_{4} / \mathrm{Pt}_{\mathrm{O}_{2}} .\end{array}$ & $\begin{array}{c}\text { Potential } \\
\mathrm{Pt}_{\mathrm{O}_{2}} / \frac{\mathrm{N}}{\mathrm{I}} \mathrm{H} \mathrm{SO}_{4}\end{array}$ \\
\hline I hour after stopping polarising current & r'346 & $-1 \cdot 069$ \\
\hline Immediately after addition of $\mathrm{K}_{2} \mathrm{~S}_{2} \mathrm{O}_{8}$ & $r \cdot 305$ & $-\mathrm{I} \cdot 028$ \\
\hline Io days later & $1 \cdot 3 \circ 5$ & $-I \cdot 028$ \\
\hline 8 weeks later $\quad \ldots \quad \ldots \quad \ldots$ & $I \cdot 287$ & -I'oro \\
\hline
\end{tabular}




\section{POTENTIAL OF THE HYDROGEN-OXYGEN CELL}

From these results it would appear as if the presence of a small quantity of persulphuric acid, which might be formed during electrolysis, would account for the high potential observed and maintained for so long by electrolytically polarised electrodes, the presence of the persulphuric acid rendering the separation of the excess of oxygen from the supersaturated electrode extremely slow.

A platinum electrode was next employed, consisting of a glass tube platinised by the method described above. This electrode was carefully covered with platinum black thoroughly cleaned with nitric acid, hydrochloric acid, chromic acid and distilled water. It was polarised for 72 hours in $\frac{N}{I}$ sodium hydrate, and allowed to stand over night with a current of oxygen gas passing through the liquid. A high potential difference was first obtained$\mathrm{I} \cdot 366$ volt, which rapidly sank to a constant value of $\mathrm{I} \cdot 073$ volt, and remained constant for eight days.

Another experiment was made in the same way, in which I cc. $\frac{\mathrm{N}}{\mathrm{YO}} \mathrm{K}_{2} \mathrm{~S}_{2} \mathrm{O}_{8}$ solution was added to the oxygen electrode. (This corresponds to a concentration of about $\mathrm{I}$ gram molecule of $\mathrm{K}_{2} \mathrm{~S}_{2} \mathrm{O}_{8}$ in 500 litres.) The potential after polarising was $1 \cdot 35^{\circ}$ volt, and ten days later had only fallen to $r^{\prime} 3^{28}$ volt. These results are shown in Table VI.

The electrodes used in these last two series of measurements were extremely thin, and hence the saturation of the platinum with gas at the pressure of the experiment, and the discharge of gas from the supersaturated electrode, was rapid, as shown in the above table of results.

These electrodes gave the same value for the hydrogen-oxygen potential, independently of the method of charging the electrode with gas, and this potential corresponds to that calculated from the Helmholtz formula :-

$$
\pi=\frac{\mathrm{Q}}{\mathrm{F}}+\mathrm{T} \frac{d \pi}{d \mathrm{~T}}
$$

where $Q=\frac{68,400}{2}$ calories, that is the heat value of the reaction-

$$
2 \mathrm{H}_{2}+\mathrm{O}_{2} \rightleftarrows{ }_{2} \mathrm{H}_{2} \mathrm{O}
$$

and $\frac{d \pi}{d \mathrm{~T}}=-0.00 \mathrm{r}_{4} \mathrm{I}$ volt according to the measurements of L. Glaser (Zeit. Physik. Chem. 44 (1894), 577).

\section{Influexce of Ozone upon the Oxygen Potential.}

The influence of ozone was next tried. A saturated solution of ozone in $\frac{\mathrm{N}}{\mathrm{I}}$ sulphuric acid was prepared by passing electrolytic oxygen through a Berthelot's ozoniser and then through a wash bottle containing $\frac{N}{I}$ sulphuric acid. When the oxygen electrode showed a constant potential against the hydrogen electrode, I-2 cc. of the ozone solution were added. At first the potential sank a little, but upon standing it rose again rapidly and reached a value of $I \cdot r 8$ volt, remaining fairly constant for several days. This is in accord with the results found by Luther and Inglis (Zeit. Physik. Chem. 43 (1903), 238.) Similarly it was found that the previous treatment of the electrodes had an influence upon the oxygen potential, just as Luther and Inglis (loc. cit.) found in the case of the ozone potential. An electrode, which was allowed to stand in chromic acid dissolved in strong sulphuric acid, 
thoroughly washed with water and then with the liquid employed in the cell, showed a much higher potential than one exposed to air. This effect could be entirely eliminated by means of the ferro-ferric bath, and each experiment commenced under comparable conditions.

The potential calculated from the Helmholtz formula is $1{ }^{\circ} 073$ volts at $17^{\circ} \mathrm{C}$. and $\mathrm{r}^{\circ} \mathrm{06} 2$ volts at $20^{\circ} \mathrm{C}$., and the foregoing results show agreement with these figures.

The high potential observed in the electrodes polarised by long electrolysis, are most likely due to the presence of persulphuric acid and ozone in the solution, as well as to the 'supersaturation of the electrodes with the gas. The presence of small quantities of these substances in solution renders the discharge of the excess of gas exceedingly slow. With electrodes charged

TABLE VI.

\begin{tabular}{|c|c|c|c|c|c|c|}
\hline & & & & & & $\begin{array}{c}\text { Potential of } \mathrm{Pt}_{\mathrm{H}_{2}} / \frac{\mathrm{N}}{\mathrm{I}} \mathrm{NaOH} / \mathrm{Pt}_{\mathrm{O}_{2}} \\
\text { Temperature }=\mathrm{I} 7^{\circ} \mathrm{C} .\end{array}$ \\
\hline $\begin{array}{l}\text { Immediate } \\
\text { current }\end{array}$ & $\begin{array}{c}\text { aft } \\
\ldots\end{array}$ & \multicolumn{2}{|c|}{ stopping } & \multicolumn{2}{|c|}{ polarising $\}$} & I'367 volt \\
\hline \multirow{2}{*}{\multicolumn{2}{|c|}{ I6 hours later... }} & & & & . & $I \cdot I 66$ \\
\hline & & $\cdots$ & $\cdots$ & $\cdots$ & $\cdots$ & 2 100 \\
\hline \multicolumn{2}{|c|}{24 hours later... } & $\cdots$ & $\cdots$ & $\cdots$ & $\cdots$ & I'073 , \\
\hline 2 days ... & ... & $\ldots$ & $\ldots$ & $\ldots$ & $\ldots$ & I'073" \\
\hline 8 days $\ldots$ & $\cdots$ & $\cdots$ & $\cdots$ & $\cdots$ & $\cdots$ & I.073 \\
\hline \multicolumn{6}{|c|}{$\left.\begin{array}{l}5 \text { minutes after stopping polarising current } \\
\text { and after addition of persulphate } \quad \ldots\end{array}\right\}$} & I’350 , \\
\hline I day ... & $\cdots$ & $\cdots$ & $\cdots$ & $\cdots$ & $\cdots$ & I'344, \\
\hline Io days... & ... & $\cdots$ & $\cdots$ & $\cdots$ & $\cdots$ & $I \cdot 328$, \\
\hline
\end{tabular}

with gas by passing it into the solution, the charge on the electrode is altered by the presence of persulphate ions. The reaction

$$
\mathrm{S}_{2} \mathrm{O}_{8}{ }^{\prime \prime}+\mathrm{O}^{\prime \prime} \rightleftarrows 2 \mathrm{SO}_{4}{ }^{\prime \prime}+\frac{1}{2} \mathrm{O}_{2}
$$

takes place only slowly, and hence the potential of an oxygen electrode in $\frac{\mathrm{N}}{\mathrm{I}}$ sulphuric acid containing persulphate ions rises slowly.;

* The author is indebted to Professor R. Luther, of Leipzig, for the following explanation of the high potential observed when electrodes are charged with oxygen by electrolysis, and also of the formation of hydrogen peroxide. As a working hypothesis the following reactions are assumed to take place at the anode :-

$$
\begin{aligned}
& \mathrm{Pt}+\mathrm{O}_{2}=\mathrm{PtO}_{2} \cdot \\
& \mathrm{PtO}_{2}+\mathrm{H}_{2} \mathrm{O}=\mathrm{PtO}+\mathrm{H}_{2} \mathrm{O}_{2}=\mathrm{PtO}+\mathrm{H}_{2} \mathrm{O}+\frac{1}{2} \mathrm{O}_{2} .
\end{aligned}
$$

These reactions are indicative of the nature of the reaction only, and do not necessarily demand that the oxides produced should have the above formula.) There is here the frequently observed case of the formation of an intermediate product, which is a more powerful oxldising agent than any other present in the 


\section{POTENTIAL OF THE HYDROGEN-OXYGEN CELL}

The influence of hydrogen peroxide, when added to the oxygen electrode, is somewhat peculiar. Haber (Zeit. Elektrochemie, vii. 442) gives the following explanation: "The hydrogen peroxide potential shows, with increasing or decreasing concentration, every change which characterises a reducing agent. With decrease of concentration, the potential of the electrode approaches that of the oxygen electrode, and with increase of concentration it approximates to that of the hydrogen electrode."

On increasing the concentration of the hydrogen peroxide in the oxygen electrode compartment the potential sank, i.e., the electrode became more negative, and so long as hydrogen peroxide remained in the neighbourhood of the electrode, the potential did not rise to its original value. It should be here noticed that although platinum black catalyses hydrogen peroxide with evolution of oxygen, this reaction is not complete. It is possible to detect a considerable amount of hydrogen peroxide in a solution which has stood in contact with platinised platinum for several weeks. The addition of ozone increases the oxygen charge upon the electrode-

$$
\mathrm{O}_{3}+\mathrm{O}^{\prime \prime}+2(\mathrm{~F}) \rightleftarrows 2 \mathrm{O}_{z} \text {, }
$$

and so increases the potential. This increase is greater, the greater the quantity of ozone solution added (compare Luther and Inglis).

\section{Conclustons.}

In the foregoing research the influence of the addition of varying quantities of hydrogen peroxide, persulphate, and ozone upon the oxygen potential have been investigated.

The results can be briefly stated as follows :-

(I) The addition of hydrogen peroxide reduces the oxygen potential.

(2) Persulphates or ozone increase the oxygen potential and diminish the rate of discharge of oxygen by an electrode supersaturated with oxygen by electrolysis.

(3) By employing electrodes of extremely thin platinum deposited upon glass and platinised, the same potential was obtained independently of the method of charging the electrodes with oxygen.

(4) The results obtained with the thin platinised platinum electrodes show a good agreement with the potential calculated from the Helmholtz formula.

In conclusion, I wish to express my indebtedness and thanks to Professor J. Campbell Brown for the use of his research laboratory and apparatus, and to Professor R. Luther, of Leipzig, for many suggestions and valuable advice in connection with this work.

Chemical Department, UNIVERSITY OF LIVERPOOL.

reaction, but its formation only takes place at the expense of the irreversible reaction-

$$
\mathrm{Pt}+\frac{1}{2} \mathrm{O}_{2}=\mathrm{PtO} \text {. }
$$

and hence, when the surface of the platinum is covered with the oxide, the high potential and the formation of hydrogen peroxide cease.

Electrodes, treated so as to cover them with a film of oxide, do not show the anomalous behaviour of the ordinary electrodes, and iridium electrodes covered with iridium black show the same potential of r.065 volt, independently of the method of charging the electrodes.

Regarding the oxides and oxidation of platinum, see Wöhler, Zeit. Anorg. Chem. 40 (I904), 423 . 